\title{
42. HYDROLOGIC AND THERMAL CONDITIONS AT A SEDIMENT/BASALT INTERFACE: IMPLICATIONS FOR INTERPRETATION OF FIELD MEASUREMENTS AT MIDDLE VALLEY ${ }^{1}$
}

\author{
J.U. Bessler, ${ }^{2}$ L. Smith, ${ }^{2}$ and E.E. Davis ${ }^{3}$
}

\begin{abstract}
Numerical simulations of hydrothermal convection in a sedimented ridge setting are presented to examine relationships between the large-scale permeability of basement, the vigor of convective circulation, the aspect ratio of convection cells, and the resulting magnitude of lateral differences in temperature $(\Delta T)$ and effective pressure $\left(\Delta P_{E}\right)$ along a sediment/basalt interface. These modeling results provide insight to hydrologic conditions within Middle Valley and allow us to explore possible relations between the single-borehole permeability measurements made during Leg 139 and the effective permeability of the basement rock at the basin scale. With an assumed basal heat flux of $750 \mathrm{~mW} / \mathrm{m}^{2}$, there is a permeability range $\left(5 \times 10^{-16}\right.$ to $\left.10^{-15} \mathrm{~m}^{2}\right)$ beyond that corresponding to the onset of convection, where $\Delta \mathrm{T}$ and $\Delta \mathrm{P}_{\mathrm{E}}$ increase towards their peak values. Higher aspect ratio convection leads to greater variations in temperature and effective pressure along the interface. Over a permeability range of 2 orders of magnitude $\left(10^{-15}\right.$ to $\left.10^{-13} \mathrm{~m}^{2}\right), \Delta \mathrm{T}$ and $\Delta \mathrm{P}_{\mathrm{E}}$ decrease as the pressure gradients driving the steady convective flow decrease, as convection becomes more vigorous, and as the entire system is cooled. At yet higher permeability values, unsteady convection is the norm and $\Delta \mathrm{T}$ and $\Delta \mathrm{P}_{\mathrm{E}}$ decline to values less than $20^{\circ} \mathrm{C}$ and $0.10 \mathrm{MPa}$, respectively. If arguments in support of a near-isothermal sediment/basement interface in Middle Valley are valid, then the implication follows that the effective permeability of the hydrothermal system is considerably greater than the values measured in deeper sections of Hole 857D and in Hole 858G. In this case it is possible that discrete zones of much higher permeability, such as those encountered at several depths in Hole 857D, are sufficiently well connected to substantially increase the large-scale permeability of the sill/sediment sequence and upper igneous basement.
\end{abstract}

\section{INTRODUCTION}

The objective of this chapter is to explore the potential magnitude of fluid pressure and temperature differences at and beneath a sediment/basement interface in a sedimented-ridge setting. Calculations of this kind are helpful in determining the extent to which subsurface temperature and pressure measurements can resolve questions related to the vigor of convective circulation in Middle Valley and other sedimented, hydrothermally active seafloor environments. Our intent is to better understand relations between the large-scale permeability of basalts along a ridge axis, the vigor of convective circulation, the magnitude of buoyancy-induced pressure differences that drive convective circulation, the aspect ratio of convection, and the resulting character of lateral temperature gradients in the permeable basement.

Figure 1 shows the idealized geometries that are modeled. In both cases, we consider a domain $2000 \mathrm{~m}$ wide and $1000 \mathrm{~m}$ deep, with no topographic relief on the seafloor. In configuration one, $500 \mathrm{~m}$ of permeable basalt (layer 2) are overlain by $500 \mathrm{~m}$ of lower permeability sediment (layer 1). The setting is representative of a region where convection occurs in permeable basement underlying a uniform blanket of lower-permeability sediments. In configuration two, a local basement high penetrates the sediments, reaching to within $200 \mathrm{~m}$ of the seafloor. A spatially uniform heat flux is imposed at the base of the model domain. With the assumption of a uniform heat input, fluid movement will occur only as a result of "supercritical" convection. This situation contrasts with that where a lateral gradient in fluid density is imposed on the model domain, either as a consequence of a spatially variable heat input, or topographic relief on the basement surface. In particular, these latter cases allow the possibility of "subcritical convection," as proposed to occur on the ridge flanks (e.g., Fisher et al., 1990).

\footnotetext{
' Mottl, M.J., Davis, E.E., Fisher, A.T., and Slack, J.F. (Eds.), 1994. Proc. ODP, Sci. Results, 139: College Station, TX (Ocean Drilling Program).

${ }^{2}$ Department of Geological Sciences, University of British Columbia, Vancouver, B.C., Canada V6T 1 Z4.

${ }^{3}$ Pacific Geoscience Centre, Geological Survey of Canada, Sydney, B.C., Canada V8L
}

Permeability measurements in Middle Valley have been made using drillstem packers in two deep reentry holes drilled during Leg 139 (Becker et al., this volume). Estimates of permeability in the sill/sediment sequence (Hole 857D) and extrusive igneous basement (Hole $858 \mathrm{G}$ ) average on the order of $10^{-14} \mathrm{~m}^{2}$. These values are consistent with other measurements in young oceanic crust (e.g., Anderson et al., 1985; Becker, 1990). Several discrete zones of high permeability were also encountered in Hole $857 \mathrm{D}$, with apparent values on the order of $10^{-10} \mathrm{~m}^{2}$ (Becker et al., this volume). Singleborehole permeability estimates typically yield values representative of length scales on the order of $10 \mathrm{~m}$ or less. These measurements reflect two different "hydraulic elements" in the network of fractures that likely provide the main pathways for fluid flow. The degree to which each of these hydraulic elements may be representative of the effective permeability that applies on the scale of the convective circulation is of fundamental importance in characterizing the hydrothermal system within Middle Valley. This issue cannot be resolved solely on the basis of hydraulic tests in single boreholes. Large-scale hydrologic simulations, constrained by observations of fluid pressure and formation temperature, provide the best opportunity for obtaining estimates of effective permeability on the basin scale (e.g., Woodbury and Smith, 1988).

Ideally, we could carry out a hydrologic inversion to estimate the large-scale permeability structure in the vicinity of the boreholes completed during Leg 139. As a consequence of both downhole thermal disturbances during drilling and technical difficulties in the collection of high-quality data, observations of borehole temperature and formation pressure in Middle Valley collected during and after Leg 139 are few in number and do not provide a clear picture of thermal and hydrologic conditions in the subsurface. Constraints on the geometry of the boundary between relatively low-permeability sediment and higherpermeability basement from seismic reflection data are imprecise. Thus, it is unrealistic to think in terms of model calibration and direct comparison to specific profiles through Middle Valley. Based on a set of internally consistent inferences, however, it is reasonable to speculate that the hydrologic unit beneath the sediment cover has sufficient permeability to promote nearly isothermal conditions along its upper boundary (Davis and Villinger, 1992; Davis and Wang, this volume). 

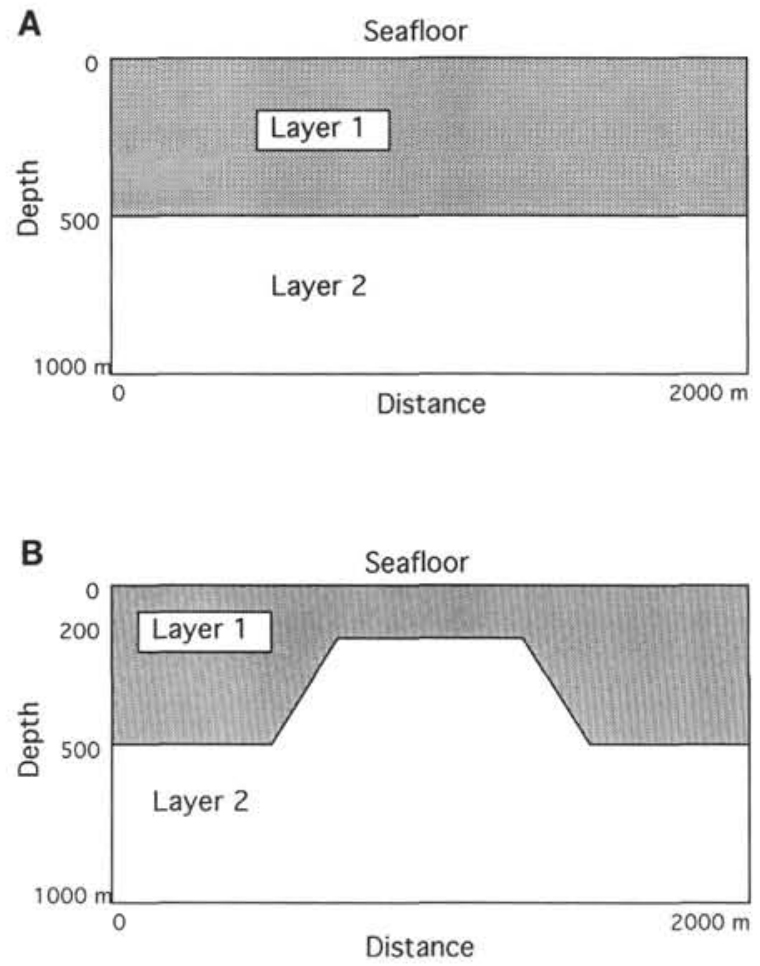

Figure 1. Geometric configurations examined in this study. A. Horizontal interface model. B. Local basement high.

The modeling results presented here will suggest that this interpretation is consistent with a large-scale basement permeability on the order of $10^{-13}$ to $10^{-12} \mathrm{~m}^{2}$ or higher. Our calculations will also point to the utility and potential limitations in using temperature and formation pressure measurements to quantify the vigor of convective circulation.

\section{NUMERICAL PROCEDURE}

The mathematical model characterizing single-phase fluid circulation in a submarine hydrothermal system is expressed by two coupled differential equations describing fluid flow and heat transfer; by equations of state for the temperature and pressure dependence of fluid density, specific heat, and fluid viscosity; and by the boundary conditions for both the fluid flow and thermal problems. The fluidflow equation is normally cast in terms of fluid pressures. The results presented here are based on a formulation using an equivalent hydraulic head (e.g., Forster and Smith, 1989). Total pressure can easily be recovered from the solution for the equivalent hydraulic head. We assume local thermal equilibrium between the fluid and rock matrix. See Lowell (1991) for a summary of the governing equations and a recent review of model studies that have addressed related aspects of high-temperature submarine convection.

An effective pressure $\left(\mathrm{P}_{E}\right)$ can be defined as the total pressure $(p)$ at a given point, minus the local thermal hydrostat $\left(\mathrm{P}_{H}\right)$. The local hydrostat is corrected for depth-dependent variations in fluid density $(\rho)$ originating from the vertical temperature gradient. At point $(x, z)$ :

$$
P_{E}(\mathrm{x}, \mathrm{z})=p(\mathrm{x}, \mathrm{z})-P_{H}(\mathrm{x}, \mathrm{z})=p(\mathrm{x}, \mathrm{z})-\int_{z}^{0} \rho g \mathrm{dz}
$$

A map of effective pressure provides insight to the overall character of the vertical component of the hydraulic gradient. Regions where $\mathrm{P}_{E}$ is negative represent underpressured regions, promoting a downward flow component. Where $P_{E}$ is positive, overpressures exist that promote an upward flow component. Along a $\mathrm{P}_{E}=0$ contour, the local fluid pressure exactly balances the weight of the overlying column of water (neutral buoyancy). For a borehole that has reequilibrated to predrilling temperature conditions, $P_{E}$ predicts the height of the water column in the borehole, relative to mean sea level. Note that the magnitude and orientation of a local velocity vector cannot be directly inferred from the values of $P_{E}$. The average linear pore-water velocity can be obtained from the relation:

$$
v=-(k / \theta \mu)(\nabla \mathrm{p}-\rho g)
$$

where $k$ is permeability, $\theta$ is effective porosity, and $\mu$ the local value of the fluid viscosity (varying with temperature and pressure).

The nonlinear equations describing the fluid flow and thermal regimes are solved using a Galerkin finite-element procedure, with a Picard iteration scheme. A one-dimensional heat conduction equation is first solved to calculate temperatures at each node in the finite element grid. These temperature values are used only to obtain initial values for the temperature-dependent fluid properties needed in solving the fluid flow and heat transfer equations. Prior to calculation of the fluid properties, the conductive temperatures are multiplied by an arbitrary constant that we have allowed to range between 0.1 and 2.0. As discussed below, this model parameter influences the aspect ratio of the convection cells that develop during the subsequent iterative solution of the governing equations. Water properties are evaluated using relations for pure water given by Keenen et al. (1978) for density and specific heat, by Watson et al. (1981) for viscosity, and by Kestin (1978) for thermal conductivity.

Numerical solutions of convective circulation require a fine computational mesh when solving problems involving higher-temperature regimes. At high temperatures the extent of the nonlinear dependence of fluid properties on temperature is appreciable, which can create problems in iterating toward a stable solution. In addition, fluid velocities are higher and the flow tends to be focused into boundary layers. A mesh with 50 by 250 grid elements is used in the simulations reported here. Initially the mesh has a uniform spacing with $\Delta x=8 \mathrm{~m}$ and $\Delta z=20 \mathrm{~m}$. Our computer code incorporates a feature whereby the mesh is adjusted during the iterative solution to tighten the grid spacing in regions of higher fluid velocity if a local Peclet number criterion is not met.

Parameters of the model are summarized in Table 1. The seafloor is isobaric, which permits limited fluid recharge and discharge through the sediment cover. All other fluid-flow boundaries are impermeable. The lateral extent of the model domain is specified somewhat arbitrarily as $2000 \mathrm{~m}$. With a basement layer $500 \mathrm{~m}$ thick, the width to depth ratio of the hydrologic unit within which supercritical convection can occur is $4: 1$. The lateral dimension is important to the extent that it influences the aspect ratio of the integer number of convection cells that develop within the basement layer. For the purpose of emphasizing the role of permeability in determining the fluid pressure and thermal fields, we have assumed single values for the porosity and solid-phase thermal conductivity for both the sediment and basement layers. Heat input at the base of the model is $750 \mathrm{~mW} / \mathrm{m}^{2}$, while the seafloor is an isothermal surface. The thermal conductivity of the solid/fluid composite will vary with temperature; along the upper boundary of the model domain its value is approximately $1.8 \mathrm{~W} / \mathrm{m}^{\circ} \mathrm{C}$. In a conductive regime, the temperature at the base of the model is $410^{\circ} \mathrm{C}$. This temperature is the highest that can occur within the model domain; active fluid circulation will reduce this value.

Where possible, we have solved directly for a steady-state configuration of the convective circulation. As noted in the following section, for permeability values in the neighborhood of $5 \times 10^{-13} \mathrm{~m}^{2}$ and higher, a regime is entered in which unsteady convection is the norm. In these cases, the transient equation of heat transfer must be solved to fully characterize system behavior, although we do not report the results of any transient simulations in this paper. We have confirmed that in the region of steady convection a transient simulation converges at large time to the same solution predicted by the steady state simulation, for 
Table 1. Parameter values used in simulation model.

\begin{tabular}{ll}
\hline Permeability & \\
Layer 1 & $1 \times 10^{-17} \mathrm{~m}^{2}$ \\
Layer 2 & Variable $\left(\mathrm{m}^{2}\right)$ \\
Porosity & 0.12 \\
Thermal conductivity of solid & $2.0 \mathrm{~W} / \mathrm{m}^{\circ} \mathrm{C}$ \\
Specific heat of solid & $837.2 \mathrm{~J} / \mathrm{kg}^{\circ} \mathrm{C}$ \\
Basal heat flux & $750 \mathrm{~mW} / \mathrm{m}^{2}$ \\
Fluid pressure on upper boundary & $25 \mathrm{MPa}$ \\
Temperature on upper boundary & $1.5^{\circ} \mathrm{C}$ \\
\hline
\end{tabular}

a given cell geometry. The transition from steady to unsteady convection is easily recognized in a steady-state simulation in terms of a characteristic pattern in the maximum change in temperature at the nodal points in the Picard iteration sequence. In the unsteady convective regime, rather than solving the transient problem, we have obtained maximum pressure and temperature differences along the sediment/ basement interface from one of the thermal fields calculated as the steady-state model iterates between a sequence of convective patterns. This simplification is discussed further in the following section.

As noted earlier, hydraulic testing in Hole 857D points to the occurrence within Middle Valley of discrete zones with permeabilities orders of magnitude higher than the surrounding basement (Becker et al., this volume). The spatial frequency of such zones, and the extent to which they may be interconnected and form connections with morenumerous, smaller-scale fractures that likely provide permeability on the meter- to ten-meter scale, is not resolved (see Langseth and Becker, this volume). Indeed, our hope is that model analyses of the kind presented here can provide insight to this issue. In this paper we proceed on the assumption that fluid flow and advective heat transfer within the sill/sediment sequence and the upper igneous basement can be approx imated by an isotropic porous medium model, with uniform permeability and effective porosity. However, the reader should be cognizant of the fact that this assumption is untested, and it remains to be seen whether these highly permeable discrete features are sufficiently numerous and connected to represent the fluid flux through them in terms of a conventional continuum approximation at the rift-basin scale.

\section{RESULTS}

\section{Horizontal Sediment/Basalt Interface}

Figure 2 shows the character of the hydrologic and thermal regimes for the case where the permeability of the basement is $2 \times 10^{-15}$ $\mathrm{m}^{2}$. Figure $2 \mathrm{~A}$ shows a set of scaled velocity vectors that illustrate the pattern of convective flow. In this case we have plotted the average linear pore-water velocity. Figure $2 \mathrm{~B}$ shows the temperature field while Figure $2 \mathrm{C}$ shows the distribution of effective pressure $\left(P_{E}\right)$. In this simulation, two stable convective cells develop, with an aspect ratio of $2: 1$. Flow is generally parallel to the sediment/basement interface away from the upflow and downflow limbs. Along the interface, the highest temperatures occur above the upwelling limb of the convection cells, while the lowest temperatures occur above the downwelling limb. This same pattern holds for the variation in the effective pressure along the interface. These positions along the interface are used to characterize the maximum difference in temperature and effective pressure that could be observed in boreholes penetrating to the top of the permeable basement.

While the fluid velocities in the sediment layer are at least several orders of magnitude lower than the average fluid velocity in the basement layer, there is a consistent pattern in the spatial distribution of effective pressure across both of the layers. Supercritical convection in the permeable basement creates lateral gradients in fluid density within the sediment layer, which in turn promotes subcritical convection in the sediments. The pattern of convection in the lowerpermeability sediments is directly linked to that in the basement layer. The fluid velocities are such, however, that heat transfer is conductive. Within the convecting layer, away from the upwelling and down-
A
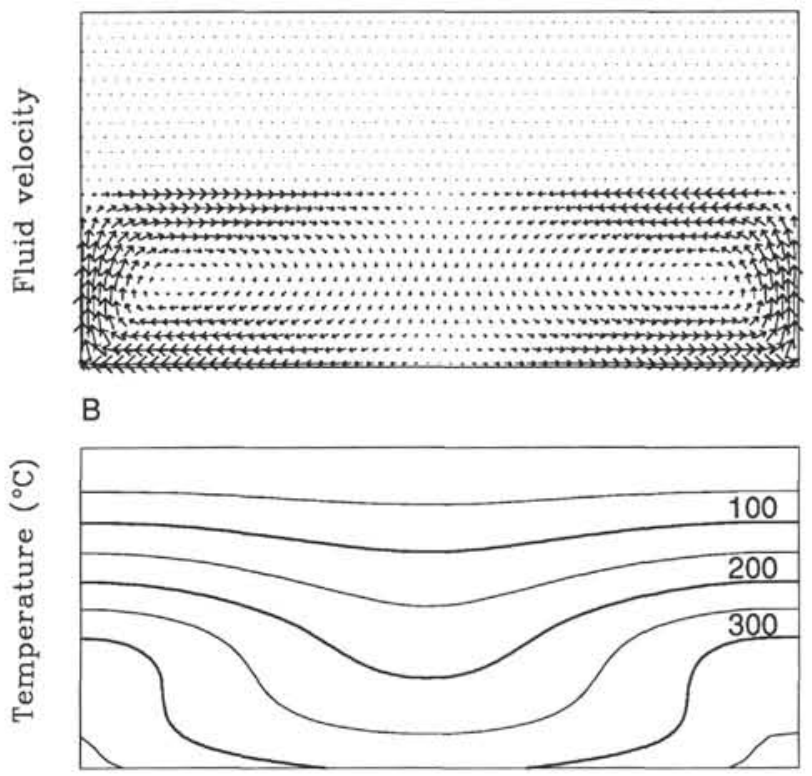

C

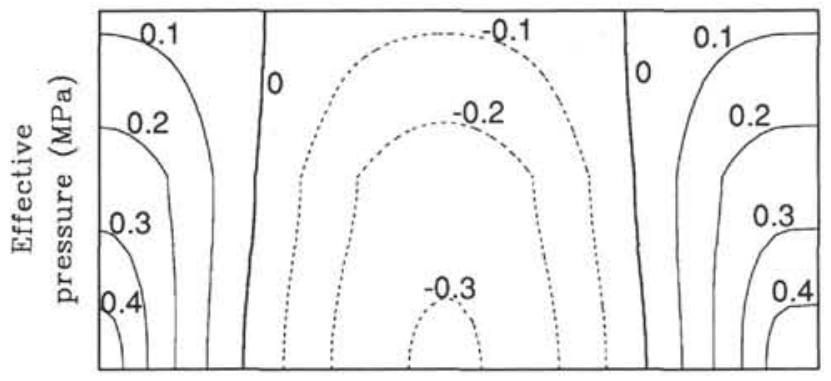

Figure 2. Two-cell convective system for the horizontal interface model with basalt permeability equal to $1 \times 10^{-14} \mathrm{~m}^{2}$. Domain is $2 \mathrm{~km}$ wide, $1 \mathrm{~km}$ in depth. A. Scaled velocity vectors, plotted relative to the maximum fluid velocity. B. Temperature field. C. Effective pressure distribution. Only selected velocity vectors are shown; pattern does not reflect the resolution of the finite element grid.

welling limbs, the lines of equal effective pressure are nearly vertical. In a uniformly homogeneous medium, this behavior implies that in those regions of the convection cells, calculations of the in-situ effective pressure would not be strongly dependent on the length of the open borehole in which the measurement of total pressure was made.

The conventional form of the Rayleigh number $\left(R_{a}\right)$ is defined on the basis of the temperature difference $(\Delta T)$ between isothermal upper and lower boundaries. Assuming a linear dependence between $\Delta T$ and the basal heat flux, it is possible to recast the Rayleigh number in an equivalent form that applies to the situation in which the upper boundary is isothermal and the lower boundary has a specified heat flux. Values of $R_{a}$ defined in this way will correspond when the thermal regime is conductive. For the situation in Figure 2, a value of $R_{a}$ equal to 104 is estimated for the basalt layer. Fluid properties used in calculating $R_{a}$ are tied to the average temperature in the convecting layer.

The Rayleigh number is given here simply to indicate that our simulations are consistent with the predicted onset of convective circulation above a critical Rayleigh number. A simulation completed with a permeability of $5 \times 10^{-16} \mathrm{~m}^{2}$ did not convect, whereas at a permeability of $8 \times 10^{-16} \mathrm{~m}^{2}$, stable convection can occur. It should be noted that the Rayleigh number is generally inadequate as a measure of the vigor of convective circulation in a submarine hydrothermal system. In this geologic setting, the assignment of a basal heat flux, rather than a specified temperature, is a better approximation to the 
physics of the problem. In its conventional form the Rayleigh number does not account for the overall cooling of the system as the vigor of the convective flow increases. In addition, at higher temperatures, the spatial differences in fluid properties that result from the temperature variations make it difficult to identify a single, representative value for a given fluid property. If the value of $R_{a}$ is back-calculated from the solution for the thermal field, it will exhibit a nonlinear variation with permeability.

It is important to recognize that downflow in the center of the model domain with upflow on the sides is not a unique flow geometry (Fig. 2A). An equally valid solution can be obtained in this symmetric problem with upflow in the center of the model and downflow on the sides. The calculated pattern of convection depends upon machine roundoff errors associated with the values of fluid properties calculated from a prior estimate of the temperature field, which is required for the first iteration on the fluid-flow equation. Our experience also shows that stable cell geometries with aspect ratios other than 2:1 may emerge. Figure 3 shows plots corresponding to those presented in Figure 2, but for a flow system that stabilizes into a pattern with three cells (an aspect ratio of 1.33:1). The only difference in the setup of the problem used to calculate the regimes shown in Figures 2 and 3 is a different constant multiplying the conductive solution that is used to provide initial values for the temperature-dependent fluid properties (a value of 1.0 in the case shown in Fig. 2 and 0.9 in the case shown in Fig. 3). A four-cell geometry, with an aspect ratio of 1:1, is also a stable solution for this model domain. The number of convection cells that will form within the simulation domain cannot be predicted a priori. If, however, the problem is rerun with the same starting condition, the aspect ratio is maintained. To provide a consistent basis in summarizing system behavior, cell geometries with the same aspect ratio are compared as a group. This sensitive dependence on initial estimates of fluid properties and on model parameters arises as a consequence of the uniform heat-flow condition we impose on the base of the model, as well as the symmetry in the geologic structure.

Table 2 is a compilation of a number of parameters that characterize the hydrologic and thermal regimes for the systems shown in Figures 2 and 3, and for a second set of simulations with a basement permeability 5 times higher $\left(1 \times 10^{-14} \mathrm{~m}^{2}\right)$. As a simple measure of the vigor of convection, we use the average and maximum values of the fluid velocity in the convecting layer. Inspection of Table 2 shows:

1. Within this permeability range, the temperature variation along the interface declines with the increase in the permeability of the basement unit. This behavior occurs because of a lower temperature above the upwelling limb of a convection cell, and a higher temperature above the downwelling limb, for the more permeable medium.

2. The temperature variation along the interface is smaller in a convective pattern with a lower aspect ratio. Above an upwelling limb, the temperature at the interface is lower and above a downwelling limb it is higher, when comparing a three-cell to two-cell geometry at the same permeability value.

3. The differences in effective pressure that develop to drive the convective circulation are smaller in a higher-permeability basement unit. Although the magnitude of the underpressures and overpressures is lower, convection is more vigorous, leading to a somewhat cooler thermal regime. The magnitude of the overpressures and underpressures is also lower in a three-cell geometry, when compared with the two-cell geometry. With a lower aspect ratio, smaller pressure gradients are needed to drive the convective flow. These responses lead to smaller differences in the effective pressure along the interface for a more permeable basement, and in the convection pattern with a smaller aspect ratio.

4. The average fluid velocity is not sensitive to the difference in the aspect ratio of the cells, the maximum velocity is only slightly lower in the three-cell geometry in comparison to the two-cell geometry. In contrast, fluid velocity is sensitive to changes in permeability, the maximum velocity approximately doubles for the fivefold in- crease in permeability. As indicated in Equation 2, the magnitude of the average linear pore-water velocity will vary inversely with the value assumed for the effective porosity. For example, if we had assumed an effective porosity 3 times smaller than that given in Table 1 , the fluid velocities would increase by a factor of 3 .

Figure 4 is a summary of the maximum temperature difference along the sediment/basalt interface, plotted as a function of the permeability of the basalt layer. Two curves are shown, one for an aspect ratio of 2:1 (two cells), the other for an aspect ratio of 1.33:1 (three cells). Both the positioning of these curves along the permeability axis and the height of the curves at a given permeability value are specific to the geometry of the model domain and the thermal properties listed in Table 1. For permeabilities less than $5 \times 10^{-16} \mathrm{~m}^{2}$, no stable convection is established. The temperature difference along the interface is zero because the conductive isotherms are horizontal. With convection, the consequent warping of the isotherms creates lateral temperature gradients. The temperature difference along the interface peaks in the situation where the system is beyond the critical condition for the onset of stable convection, but the circulation can still be characterized as having a relatively weak convective flow. At higher permeabilities than this, the increased vigor of the convective circulation (and thus the increased efficiency of advective heat transfer) leads to an overall lowering of temperatures along the interface.

The temperature difference along the interface is also lower for the convective pattern with a lower aspect ratio. Among the numerous ( $>200$ ) trials that were carried out to construct Figure 4, a four-cell geometry with an aspect ratio of 1:1 occurred relatively infrequently. Because it is not possible to predict a priori the number of convection cells that will form, in some cases numerous trials had to be carried out using different constants multiplying the initial temperature estimates to obtain solutions with the different aspect ratios. In the permeability range from $5 \times 10^{-15}$ to $8 \times 10^{-15} \mathrm{~m}^{2}$, with a four-cell geometry, the maximum temperature difference along the interface ranged from $36^{\circ}$ to $40^{\circ} \mathrm{C}$. These values are consistent with a smaller temperature difference along the interface in a convection pattern with a smaller aspect ratio, although the exact relationship has yet to be determined over a broad permeability range.

For basalt permeabilities greater than $10^{-12} \mathrm{~m}^{2}$, the temperature along the interface varies by less than $20^{\circ} \mathrm{C}$ between regions of upflow and downflow (Fig. 4). With a permeability of $10^{-12} \mathrm{~m}^{2}$, the average fluid velocity in layer 2 is approximately $20.8 \mathrm{~m} / \mathrm{yr}$. The maximum fluid velocity is roughly 5 times greater than this value. At higher permeability values than this, the concentration of the flow into boundary layers restricts the usefulness of the average fluid velocity as a measure of the overall vigor of convection.

The points plotted in Figure 4 as open symbols must be interpreted with caution. At these higher permeabilities, unsteady convection is the norm and we have simply picked a representative temperature from one of the thermal fields calculated as the steady-state model iterates between a sequence of convective patterns. It is also difficult to represent the unsteady convective pattern in terms of a single value for the aspect ratio, as was required in constructing Figure 4. We feel these points are reliable to the extent that they indicate the tendency toward an isothermal interface in this permeability range.

While the calculated values for the maximum temperature and fluid pressure difference along the sediment/basalt interface are specific to the assumed model geometry and thermal properties, a general behavior is apparent. The greatest difference in temperatures along the interface occur in a well-developed but weakly convecting system. Convection cells with a higher aspect ratio lead to greater temperature differences along the interface. Small temperature differences (say, less than $20^{\circ} \mathrm{C}$ ) along the sediment/basalt interface suggest that the bulk permeability of the layer in which convection occurs must be greater than $10^{-12} \mathrm{~m}^{2}$. However, it may be difficult to infer the degree to which the bulk permeability could exceed this value because of subsequent small changes in the temperature difference 


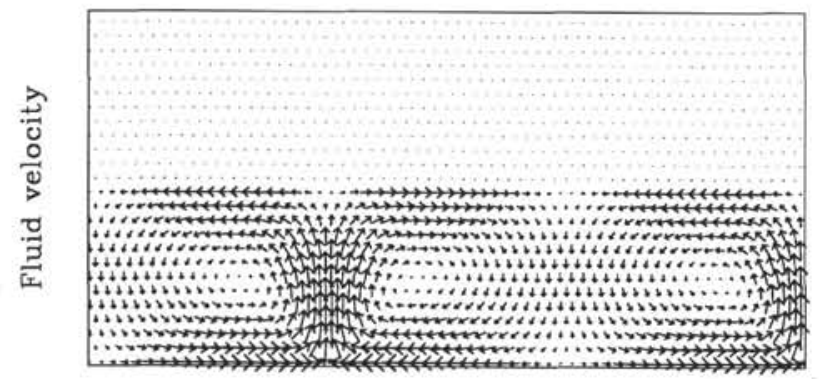

B

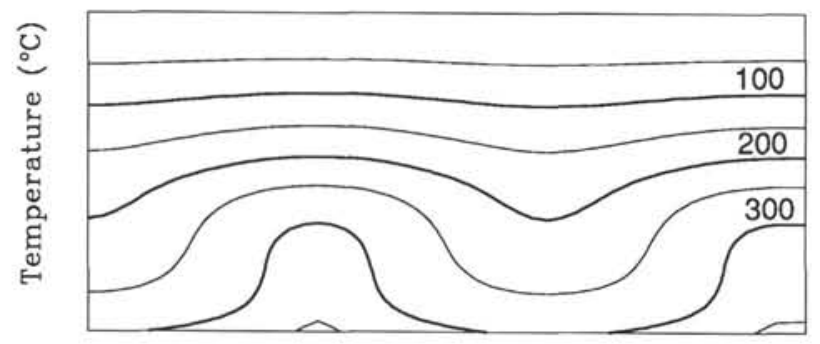

C

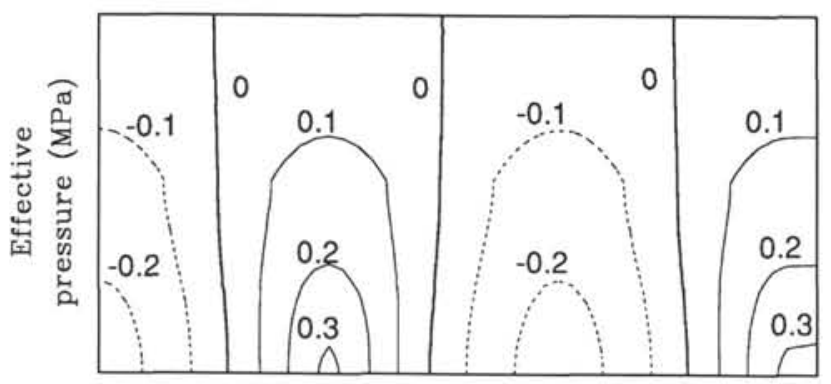

Figure 3 . Three-cell convective system for the horizontal interface model with basalt permeability equal to $1 \times 10^{-14} \mathrm{~m}^{2}$. Domain is $2 \mathrm{~km}$ wide, $1 \mathrm{~km}$ in depth. A. Scaled velocity vectors, plotted relative to the maximum fluid velocity. $\mathbf{B}$. Temperature field. C. Effective pressure distribution. Only selected velocity vectors are shown; pattern does not reflect the resolution of the finite element grid.

along the interface for order of magnitude increases in the permeability of the basalt layer. Additional comments relevant to the interpretation of measurements from Middle Valley are deferred to the "Discussion" section of this paper.

Figure 5 shows the maximum difference in the effective pressure observed along the sediment/basalt interface for the two- and three-cell geometries. Below the threshold of convective circulation, the effective pressure is everywhere equal to zero. The total pressure at any position $(\mathrm{x}, \mathrm{z})$ is given as the weight of the overlying column of water at that point (i.e., a hydrostat defined by the geotherm). With the establishment of a weak convective flow, at a permeability of approximately $10^{-15} \mathrm{~m}^{2}$ for the geometry and medium properties we consider, the difference in the values of effective fluid pressure along the interface is at its highest value $(0.54 \mathrm{MPa}$ for a cell aspect ratio of $2: 1$, and $0.30 \mathrm{MPa}$ for a cell aspect ratio of 1.33:1). The maximum difference in effective pressure is recorded when one observation point is located above the upwelling limb of the convection cell and the other is located above the downwelling limb. To place this difference in effective pressure in some context, recall that in a cold, isothermal system, a value of $0.54 \mathrm{MPa}$ would correspond to a difference in water levels of $54 \mathrm{~m}$ in sealed boreholes open only at the interface.

The difference in effective pressure along the sediment/basalt interface decreases in systems with higher permeability, reflecting the overall reduction in the hydraulic gradients needed to drive convec-

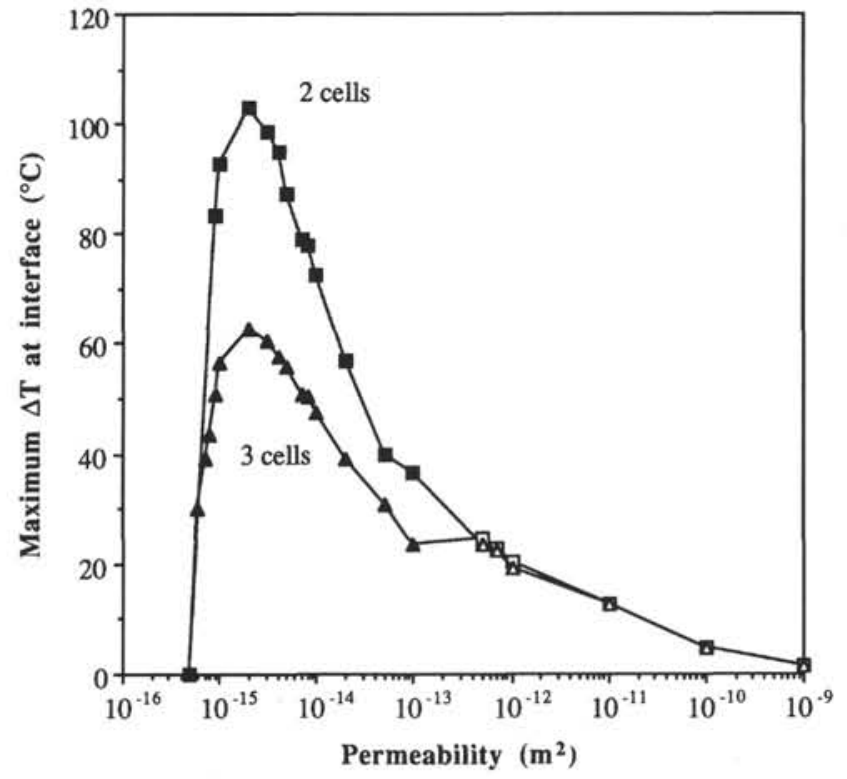

Figure 4. Maximum difference in temperature along the sediment/basalt interface, plotted as a function of the permeability of the basalt layer for the horizontal interface model. See text for discussion of solid and open symbols.

Table 2. Selected properties of the hydraulic and thermal regime for the horizontal interface model.

\begin{tabular}{lcccccc}
\hline & \multicolumn{2}{c}{ Two-cell geometry } & & \multicolumn{2}{c}{ Three-cell geometry } \\
\cline { 6 - 7 } Permeability $\left(\mathrm{m}^{2}\right)$ & $2 \times 10^{-15}$ & $1 \times 10^{-14}$ & & $2 \times 10^{-15}$ & $1 \times 10^{-14}$ \\
\hline $\mathrm{T}_{\max }\left({ }^{\circ} \mathrm{C}\right)$ & 248 & 224 & & 220 & 210 \\
$\mathrm{~T}_{\min }\left({ }^{\circ} \mathrm{C}\right)$ & 145 & 152 & & 157 & 163 \\
$\Delta \mathrm{T}$ inter $\left({ }^{\circ} \mathrm{C}\right)$ & 103 & 72 & & 63 & 47 \\
$\mathrm{P}_{\text {under }}(\mathrm{MPa})$ & 0.30 & 0.20 & & 0.25 & 0.15 \\
$\mathrm{P}_{\text {over }}(\mathrm{MPa})$ & 0.45 & 0.20 & & 0.30 & 0.15 \\
$\Delta \mathrm{P}_{\text {inter }}(\mathrm{MPa})$ & 0.54 & 0.32 & & 0.30 & 0.18 \\
$\mathrm{~V}_{\mathrm{a}}(\mathrm{m} / \mathrm{yr})$ & 1.25 & 2.92 & & 1.25 & 2.92 \\
$\mathrm{~V}_{\max }(\mathrm{m} / \mathrm{yr})$ & 4.17 & 7.50 & & 3.42 & 6.83 \\
\hline
\end{tabular}

Notes: $\mathrm{T}_{\mathrm{max}}=$ maximum temperature along sediment/basement interface; $T_{\min }=$ minimum temperature along sediment/basement interface; $\Delta \mathrm{T}$ inter $=$ maximum temperature difference along interface; $P_{\text {tinder }}=$ representative value for highest underpressures within model domain; $\mathrm{P}_{\text {over }}=$ representative value for highest overpressures within model domain; $\Delta \mathrm{P}_{\text {inter }}=$ maximum pressure difference along sediment/basement interface; $\mathrm{V}_{\mathrm{a}}=$ average value for fluid velocity in basement layer; $\mathrm{V}_{\max }=$ maximum value for fluid velocity in basement layer.

tive flow. In the permeability range from $10^{-15}$ to $10^{-13} \mathrm{~m}^{2}$, the magnitude of the pressure differences in the basalts provides a reasonably sensitive indicator of the vigor of the convective flow. Small differences in formation pressure along the sediment/basement interface (less than $0.10 \mathrm{MPa}$ ) in a system known to be convecting implies high permeability. At permeabilities higher than $10^{-13} \mathrm{~m}^{2}$, the pressure differences become so small relative to present capabilities for accurate determination of formation pressures that, while providing an indication of vigorous convection and higher permeability, pressure measurements alone will not be helpful in further constraining the permeability of the layer in which convection is occurring. Other data, such as geochemical signatures, appear necessary to complement temperature and fluid pressure measurements. The reader is cautioned again that the open symbols in Figure 5 are equivocal, because the system at these higher permeability values is in a mode of unsteady convection. We have simply chosen a single value to represent the magnitude of the driving force. 


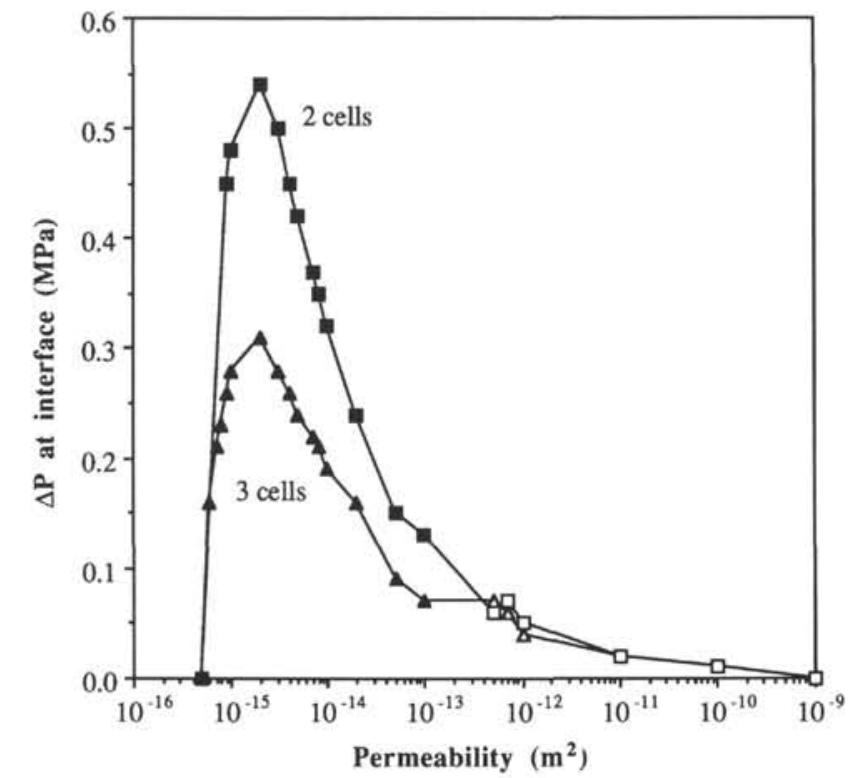

Figure 5. Maximum difference in effective pressure along the sediment/basalt interface, plotted as a function of the permeability of the basalt layer for the horizontal interface model. See text for discussion of solid and open symbols.

Table 3. Horizontal interface model: selected properties of the hydraulic and thermal regime for differing values of the basal heat flux.

\begin{tabular}{ccccc}
\hline $\begin{array}{c}\text { Basal heat flux } \\
\left(\mathrm{mW} / \mathrm{m}^{2}\right)\end{array}$ & $\Delta \mathrm{T}_{\text {inter }}\left({ }^{\circ} \mathrm{C}\right)$ & $\Delta \mathrm{P}_{\text {imier }}(\mathrm{MPa})$ & $\mathrm{V}_{\mathrm{a}}(\mathrm{m} / \mathrm{yr})$ & $\mathrm{V}_{\max }(\mathrm{m} / \mathrm{yr})$ \\
\hline $\begin{array}{c}\text { Two-cell geometry } \\
500\end{array}$ & 63 & & & \\
750 & 87 & 0.24 & 0.83 & 2.75 \\
1000 & 92 & 0.42 & 2.08 & 5.42 \\
Three-cell geometry & & & 3.25 & 11.50 \\
500 & 38 & 0.14 & 0.92 & \\
750 & 55 & 2.24 & 2.08 & 4.82 \\
1000 & 70 & 0.35 & 3.25 & 10.42 \\
\hline
\end{tabular}

Note: See Table 2 for definitions of $\Delta \mathrm{T}_{\text {inter }}, \Delta \mathrm{P}_{\text {inter }}, \mathrm{V}_{\mathrm{a}}$, and $\mathrm{V}_{\max }$.

The magnitude of the maximum fluid pressure and temperature variations along the interface varies with the magnitude of the basal heat flux. Table 3 summarizes values for the maximum temperature and fluid pressure differences along the sediment/basalt interface for three different values of the basal heat flux. The permeability of the basement is $5 \times 10^{-15} \mathrm{~m}^{2}$. Results are given for both a two- and threecell geometry. As expected, the maximum temperature and fluid pressure differences along the interface increase with the increase in the basal heat flux. So too does the vigor of the convective flow. While it is difficult to provide an accurate estimate of the average conductive heat flux beneath the depth of active fluid circulation in the vicinity of Holes 856,857 , and 858 , it is likely that the value is on the order of $500 \mathrm{~mW} / \mathrm{m}^{2}$, or higher. With respect to conditions in Middle Valley, it is more reasonable to attribute small temperature differences along the sediment/basement interface to the effects of vigorous convection, rather than to lower values for the basal heat flux.

\section{Local Buried Basement High}

Vertical relief on the sediment/basement interface will increase the magnitude of the lateral variability in temperature and effective pressure along the interface. Figure 6 shows the character of the thermal and hydrologic regimes for the configuration where permeable basalt penetrates into the sediment cover. The simulation is for a basalt per-

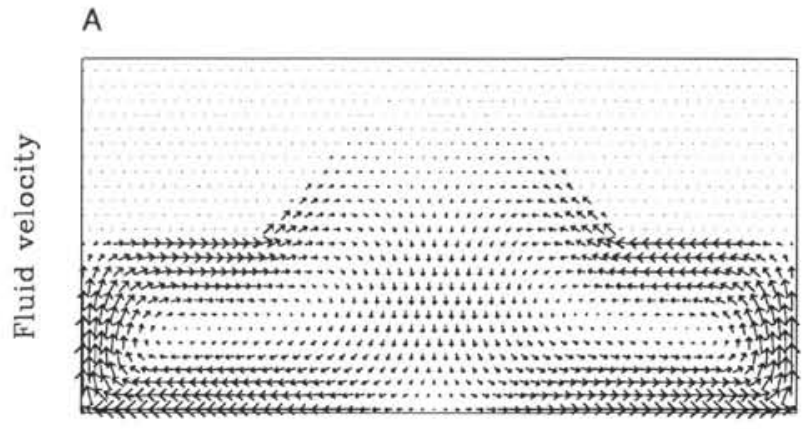

B

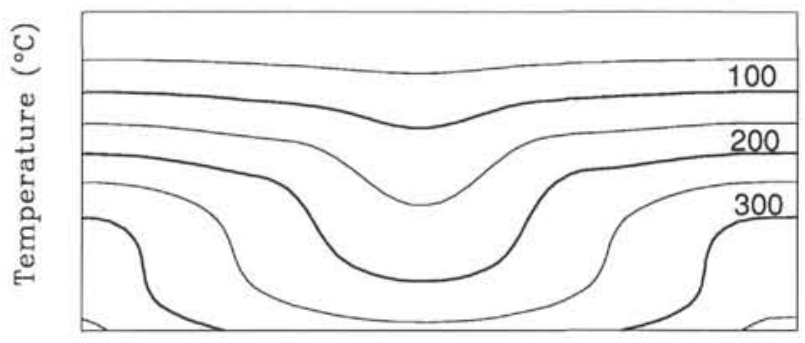

C

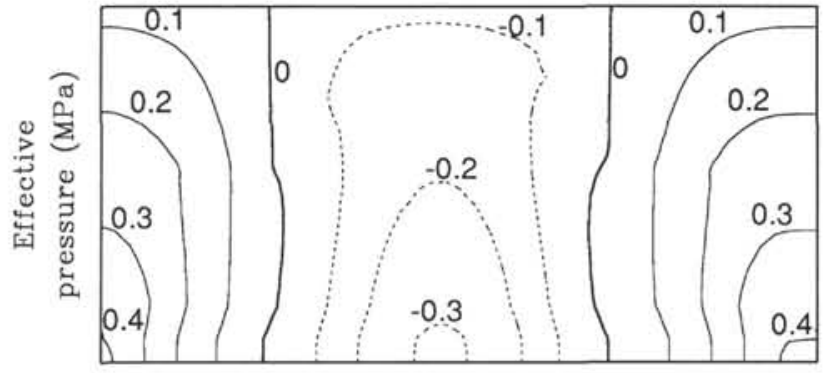

Figure 6. Convective system for the model incorporating a local basement high with a basalt permeability equal to $1 \times 10^{-14} \mathrm{~m}^{2}$. Domain is $2 \mathrm{~km}$ wide, $1 \mathrm{~km}$ in depth. A. Scaled velocity vectors, plotted relative to the maximum fluid velocity. B. Temperature field. C. Effective pressure distribution. Only selected velocity vectors are shown; pattern does not reflect the resolution of the finite element grid.

meability of $2 \times 10^{-15} \mathrm{~m}^{2}$; other medium properties are again given in Table 1. Although there is topographic relief on the basement surface, because the thermal conductivities of layer 1 and 2 are equal, fluid movement occurs as a consequence of supercritical convection.

Figure 6 illustrates a convection system with a downflow limb centered on the basement high, with upflow along the lateral boundaries of the flow domain. Regions of downflow and upflow are forced into proximity owing to the presence of the basement high. Within the basement high, there is an upwardly directed component of flow along its sides, delivering fluid to the central region of downflow. Movement of water upward into the basement high is enhanced at higher permeability values. This pattern of steady convection was observed for every case we modeled with a permeability between $1 \times$ $10^{-15}$ and $5 \times 10^{-14} \mathrm{~m}^{2}$. At higher permeability values than this, unsteady convection leads to more complex patterns of circulation within the basalt layer. Included within the flow patterns that occur in this regime are cases where the upwelling limbs of the convection cells are beneath the basement high.

In a conductive regime, the temperature contrast between the top of the basement high and the base level is $123^{\circ} \mathrm{C}$ (given the vertical separation of $300 \mathrm{~m}$ ). At a permeability of $2 \times 10^{-15} \mathrm{~m}^{2}$, this difference increases to $181^{\circ} \mathrm{C}$ because of warming that occurs along the base level above the upwelling limb of the convection cell and cooling that 
occurs at the top of the basement high, relative to that in the conductive regime. The maximum difference in the effective pressure along the interface is $0.43 \mathrm{MPa}$. In accord with the behavior seen earlier in the horizontal interface model, for a permeability equal to $1 \times 10^{-14}$ $\mathrm{m}^{2}$, fluid velocities are sufficiently high to initiate an overall cooling of the system; the temperature difference along the interface falls to $125^{\circ} \mathrm{C}$. It is worth noting that at these higher permeability values, although the system is cooler, upflow along the sides of the basement high leads to the situation where the top of the basement high is warmer than the surrounding sediments.

The maximum temperature difference along the sediment/basalt interface, plotted as a function of permeability, is shown in Figure 7. Again, open symbols indicate points that must be accepted with caution because they come from an unsteady convective regime. The onset of steady convective circulation occurs at a permeability of approximately $3 \times 10^{-16} \mathrm{~m}^{2}$. The fluctuations in $\Delta T$ at permeability values corresponding to the onset of supercritical convection reflect numerical difficulties in finding a steady convective pattern in a system with a weak convective flow. For comparative purposes, we have reproduced the $\Delta T / k$ curves shown earlier for the horizontal interface model. The effect of the local basement relief is to shift the implied association between near-isothermal conditions and largescale permeability toward higher permeability values. For the parameter values adopted here, and a vertical relief of $300 \mathrm{~m}$ on the interface, if we use a lateral temperature variation of less than $20^{\circ} \mathrm{C}$ to indicate "near-isothermal" conditions, the presence of lateral temperature differences this small suggest basin-scale permeabilities in excess of $10^{-12} \mathrm{~m}^{2}$.

Our simulations indicate that in the permeability range from $10^{-16}$ to $10^{-13} \mathrm{~m}^{2}$, downflow in the central region of the basement high is the preferred pattern of steady convection for the geometric configuration shown in Figure 1B. Upflow occurs along the sides of the basement high. Within the framework of this simple geometry, a circulation pattern with upflow in the central region of the basement high likely requires either the addition of a permeable structure connecting the basement high to the seafloor to promote the focused discharge of higher-temperature fluids, an elevated basal heat flux in the region of the basement high, or high permeability which moves the convection pattern into an unsteady regime. These configurations are being considered in ongoing studies.

\section{DISCUSSION}

The notion that hydrothermal circulation in the oceanic crust is sufficiently vigorous to maintain "isothermal" conditions at the interface between permeable igneous basement and overlying sediments is supported by the results of several field studies. These studies have demonstrated a clear inverse correlation between seafloor heat flow and local variations in sediment thickness. The correlation was first recognized on the basis of relatively widely spaced heat-flow measurements and seismic-reflection profiles collected in the Middle Valley area (Davis and Lister, 1977). Using a more dense suite of heat-flow measurements and coincident seismic reflection profiles in this same area, Davis and Villinger (1992) attempted to better define this relationship and to quantify the degree to which conditions at the sediment/basement interface are near-isothermal (and thus, as shown in this paper, to quantify the vigor of circulation). Unfortunately, the accuracy with which the sediment thickness variations could be defined was severely limited by the nature of the basement.

Basement at Middle Valley, as determined by drilling (Shipboard Scientific Party, 1992a) and multichannel seismic-reflection data (Rohr and Schmidt, this volume), comprises a thick sequence of igneous sills and interbedded sediments. At Site 857, where this sequence was penetrated by drilling, the top of the intrusive sequence and the beginning of pervasive permeability appear to coincide (Shipboard Scientific Party, 1992a). The high permeability can be inferred from the extensive depletion of mobile elements in the interbedded sedi-

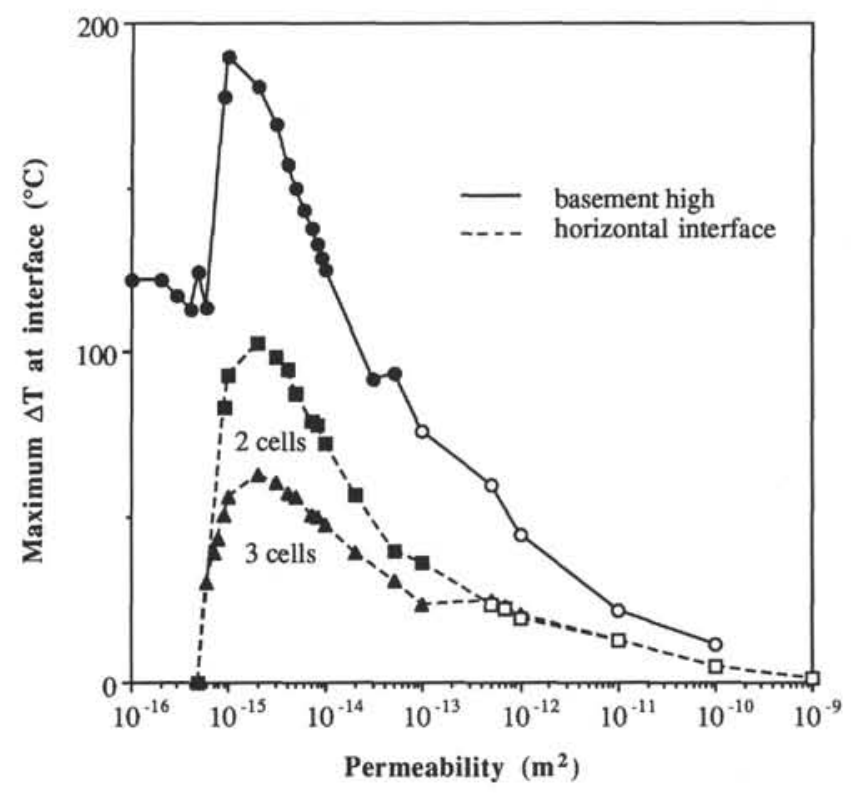

Figure 7. Maximum difference in temperature along the sediment/basalt interface, plotted as a function of the permeability of the basalt layer for the model incorporating a local basement high. See text for discussion of solid and open symbols.

ments in the sill complex, while these elements have been retained within the lower permeability sediment section. At other locations, however, the presence of isolated high-level sills that are likely not to be hydrologically significant cause the depth of permeable basement to be impossible to determine accurately, and this precludes an accurate estimate of the lateral variability in temperature at the sediment/ basement interface. We emphasize, however, that the general relationship between heat flow and sediment thickness is clear, and that it can be concluded with confidence that temperatures in the basement are more uniform than they would be if only conductive heat flow determined the thermal regime (see Davis and Villinger, 1992, fig. 13).

The high degree of mobile-element depletion observed at Site 857 requires that at some point in the recent geologic past, there has been a large-scale transfer of mobile elements by groundwater flow (Shipboard Scientific Party, 1992a). The spatial uniformity of the depletion suggests the presence of a fracture network that was hydraulically well connected on a broad range of length scales. Admittedly, this geochemical argument for high permeability does not allow us to draw direct inferences on the present-day vigor of convective circulation. Such conclusions must be based on observations of formation pressures and the thermal regime.

The best estimates of lateral temperature variations in the upper oceanic crust have been derived from seismic and heat-flow observations on the eastern flank of the Juan de Fuca Ridge, where the seismic structure is simple and sediment thickness variations are well defined (Davis et al., 1989; Davis, Chapman, et al., 1992). At one location where sediment thickness is uniform, temperatures estimated along the sediment/basement interface vary by less than $10^{\circ} \mathrm{C}$. Even where basement relief and sediment thickness variations are large, temperatures vary by less than approximately $20^{\circ} \mathrm{C}$. If the temperature differences were to scale only by the magnitude of the basal heat flux, differences in Middle Valley of less than $30^{\circ}-60^{\circ} \mathrm{C}$ would be implied. Obviously, the nature of the basalts that host hydrothermal circulation on the ridge flanks differs significantly from that at Middle Valley (extrusive basalts up to $5 \mathrm{Ma}$ in age vs. young intrusive rocks in a tectonically active area), and considerable caution must be used in drawing any parallel conclusions.

One of the objectives of Leg 139 drilling was to make direct observations of lateral variations in temperature and fluid pressure in 
the permeable basement. Unfortunately, downhole temperature logs were plagued by large disturbances caused by drilling and downhole water flow (Shipboard Scientific Party, 1992a, 1992b) and long-time observations of temperature were compromised by technical problems (Davis, Becker, et al., 1992). One constraint on hydrothermal temperatures can be made by extrapolating temperature measurements in the upper $80 \mathrm{~m}$ of the section made during drilling at Site 857 down to the depth at which significant permeability is inferred to begin (see Davis and Wang, this volume; Villinger et al., this volume). The resulting temperature, $280^{\circ} \mathrm{C}$, is remarkably close to the temperatures measured at the hydrothermal vents and estimated in the permeable formation beneath the vent field at Site 858, located roughly 2 km away (Shipboard Scientific Party, 1992b). These sparse data may not provide a representative sample, but as they stand, they suggest that the lateral temperature variability may be substantially less than the values of $30^{\circ}$ to $60^{\circ} \mathrm{C}$ suggested in the previous paragraph.

Observations of formation pressures were also made during and after Leg 139. When corrected for the anomalous density of the cold water in the open hole, formation packer and CORK measurements in Hole 857D (Becker et al., this volume; Davis, Becker, et al., 1992) indicate conditions that are close to hydrostatic (within about 0.05 $\mathrm{MPa}$; Davis and Becker, this volume). This behavior could be a result of the hole's location in a zone of lateral flow, well away from either upflow or downflow (see Fig. 2), or it could be an indication of flow in a highly permeable basement. This latter possibility is supported independently by measurements of pressure at Site 858 (Fig. 5). Fluid pressure in this hydrothermal upflow zone can be accounted for if there is a small pressure drop (i.e., a high-permeability connection) at depth between this site and Site 857 (see discussion in Davis and Becker, this volume).

Although these limited observations cannot be considered generally representative, both the estimated temperatures and pressures are consistent with the notion of a highly permeable basement unit in this sedimented-rift setting. For temperature variations along a topographically rough sediment/permeable basement interface to be significantly lower than those expected in a conductive regime, possibly as low as a few tens of ${ }^{\circ} \mathrm{C}$, requires vigorous hydrothermal circulation and basement permeability on the order of $10^{-13}$ to $10^{-12} \mathrm{~m}^{2}$ or higher (Fig. 4 and 7).

\section{CONCLUSIONS}

Numerical models of hydrothermal circulation in a sedimentedridge setting can be used to explore relations between the large-scale permeability of basalts along a ridge axis, the magnitude of buoyancy-induced pressure differences that drive convective circulation, and the vigor of the convective flow. The model results show the importance and potential limitations of measured pressures and temperatures in describing in quantitative terms hydrothermal convection in the oceanic crust. In this paper we have focused on the magnitude of differences in temperature $(\Delta T)$ and effective pressure $\left(\Delta P_{E}\right)$ along the sediment/basement interface as a means of drawing inferences on basin-scale permeability. Although such an analysis is nonunique, it does provide useful insight into conditions within Middle Valley.

Accurate measurements of lateral temperature and pressure variations can provide strong constraints on formation-scale permeability over a geologically realistic and interesting range. There is a small permeability range beyond that corresponding to the onset of supercritical convection where $\Delta \mathrm{T}$ and $\Delta \mathrm{P}_{\mathrm{E}}$ increase towards their peak values. At higher permeability values, $\Delta \mathrm{T}$ and $\Delta \mathrm{P}_{\mathrm{E}}$ decrease as the pressure gradients driving the steady convective flow decrease, as convection becomes more vigorous and as the entire system is cooled. This behavior extends over a permeability range of approximately 2 orders of magnitude. At yet higher permeability values, fluid velocities increase to the point where unsteady convection is the norm. At these permeability values, $\Delta \mathrm{T}$ and $\Delta \mathrm{P}_{\mathrm{E}}$ decline to values less than $20^{\circ} \mathrm{C}$ and $0.10 \mathrm{MPa}$, respectively.
Application of the relationships plotted in Figures 4, 5, and 7 to Middle Valley suggests that if the arguments in support of a nearisothermal sediment/basement interface are valid, the implication is that the effective permeability of the hydrothermal reservoir is considerably greater than the values measured in the deeper sections of Hole 857D and in Hole 858G. The inference follows that discrete zones of higher permeability, such as those encountered at several depths in Hole 857D, are sufficiently well connected to substantially increase the large-scale permeability of the sill/sediment sequence and upper igneous basement. Clearly, to test this hypothesis, better temperature and pressure observations are required than those made to date. Additional modeling will include an examination of the sensitivity of lateral temperature and pressure variations to variations in sediment thickness and other structural complexities, a consideration of the affects of less restricted recharge and discharge of fluids through the seafloor, and the restriction of high permeability to a limited number of discrete fracture zones.

\section{ACKNOWLEDGMENTS}

This work has been supported by a grant to L. Smith from the Natural Sciences and Engineering Research Council of Canada. Geological Survey of Canada Contribution 24893.

\section{REFERENCES}

Anderson, R.N., Zoback, M.D., Hickman, S.H., and Newmark, R.L., 1985. Permeability versus depth in the upper oceanic crust: in situ measurements in DSDPHole 504B, eastern equatorial Pacific. J. Geophys. Res., 90:36593669.

Becker, K., 1990. Measurements of the permeability of the upper oceanic crust at Hole 395A, ODP Leg 109. In Detrick, R., Honnorez, J., Bryan, W.B. Juteau, T., et al., Proc. ODP, Sci. Results, 106/109: College Station, TX (Ocean Drilling Program), 213-222.

Davis, E.E., Becker, K., Pettigrew, T., Carson, B., and MacDonald, R., 1992. CORK: a hydrologic seal and downhole observatory for deep-ocean boreholes. In Davis, E.E., Mottl, M.J., Fisher, A.T., et al., Proc. ODP, Init. Repts., 139: College Station, TX (Ocean Drilling Program), 43-53.

Davis, E.E., Chapman, D.S., Forster, C.B., and Villinger, H., 1989. Heat-flow variations correlated with buried basement topography on the Juan de Fuca Ridge flank. Nature, 342:533-537.

Davis, E.E., Chapman, D.S., Mottl, M.J., Bentkowski, W.J., Dadey, K., Forster, C., Nagihara, S., Rohr, K., Wheat, G., and Whiticar, M., 1992. FlankFlux: an experiment to study the nature of hydrothermal circulation in young oceanic crust. Can. J. Earth Sci., 29:925-952.

Davis, E.E., and Lister, C.R.B., 1977. Heat flow measured over the northern Juan de Fuca Ridge: evidence for widespread hydrothermal circulation in a highly heat transportive crust. J. Geophys. Res., 82:4845-4860.

Davis, E.E., and Villinger, H., 1992. Tectonic and thermal structure of the Middle Valley sedimented rift, northern Juan de Fuca Ridge. In Davis, E.E., Mottl, M.J., Fisher, A.T., et al., Proc. ODP Init. Repts., 139: College Station, TX (Ocean Drilling Program), 9-41.

Fisher, A.T., Becker, K., Narasimhan, T.N., Langseth, M.G., and Mottl, M.J., 1990. Passive, off-axis convection through the southern flank of the Costa Rica rift. J. Geophys. Res., 95:9343-9370.

Forster, C.B., and Smith, L., 1989. The influence of groundwater flow on thermal regimes in mountainous terrain: a model study. J. Geophys. Res., 94:9439-9451.

Keenan, J.H., Keyes, F.G., Hill, P.G., and Moore, J.G., 1978. Steam Tables: Thermodynamic Properties of Water, Including Vapor, Liquid and Solid Phases: New York (Wiley).

Kestin, J., 1978. Thermal conductivity of water and steam. Mech. Eng., 100:1255-1258.

Lowell, R.P., 1991. Modeling continental and submarine hydrothermal systems. Rev. Geophys., 29:457-476.

\footnotetext{
- Abbreviations for names of organizations and publications in ODP reference lists follow the style given in Chemical Abstracts Service Source Index (published by American Chemical Society).
} 
Shipboard Scientific Party, 1992a. Site 857. In Davis, E.E., Mottl, M.J., Fisher, A.T., et al., Proc. ODP, Init. Repts., 139: College Station, TX (Ocean Drilling Program), 283-429.

, 1992b. Site 858. In Davis, E.E., Mottl, M.J., Fisher, A.T., et al., Proc. ODP, Init. Repts., 139: College Station, TX (Ocean Drilling Program), 431-569.

Watson, J.T.R., Basu, R.J., and Sengers, J.V., 1981. An improved representative equation for the dynamic viscosity of water substance. J. Phys. Chem. Ref. Data, 9:1255-1279.
Woodbury, A.D., and Smith, L., 1988. Simultaneous inversion of hydrogeologic and thermal data, 2. Incorporation of thermal data. Water Resour. Res., 24:356-372.

Date of initial receipt: 17 December 1992

Date of acceptance: 11 August 1993

Ms 139SR-253 